\title{
SYNTHESIS OF SOME NEW 1,4-DISUBSTITUTED PIPERAZINE-2,3- DIONE DERIVATIVES OF POTENTIAL ANTHELMINTIC ACTIVITY
}

\author{
Mostafa A. Hussein ${ }^{1 *}$, and Ahmed K. Diab ${ }^{2}$
}

${ }^{1}$ Department of Pharmaceutical Organic Chemistry, Faculty of Pharmacy and ${ }^{2}$ Department of Parasitology, Faculty of Medicine, Assiut University, Assiut-71526, Egypt

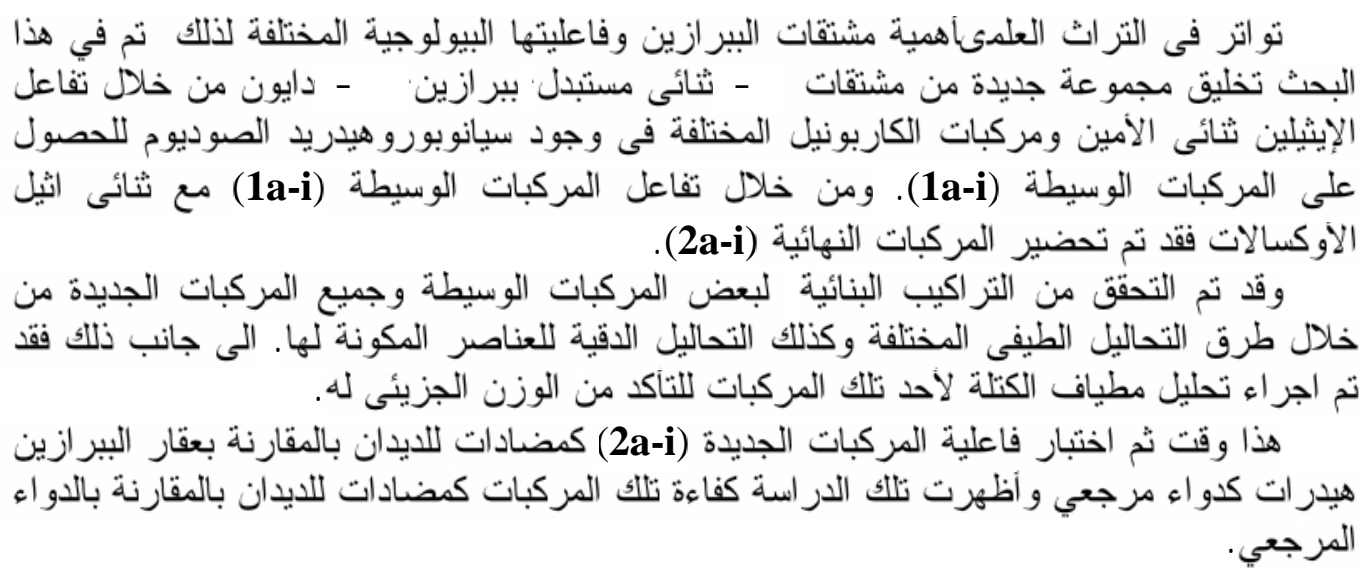

The purpose of this study based upon design and synthesis of a new series of 1,4disubstituted piperazine-2,3-dione derivatives through two steps reaction. This protocol involves the formation of $N, N^{\prime}$-Bis-(4-substituted benzyl)-ethane-1,2-diamine and $N, N^{\prime}$-Bis-[1(4-substituted phenyl)-ethyl]-ethane-1,2-diamine derivatives (1a-i) through reductive alkylation reaction from ethylenediamine and different carbonyl compounds in the presence of sodium cyanoborohydride. The second step involves reaction of compounds (1a-i) with diethyl oxalate affording the target compounds. Consequently, nine new 1,4-disubstituted piperazine-2,3-dione derivatives were synthesized as the target compounds, 1,4-Bis-(4-substituted benzyl)piperazine-2,3-dione and 1,4-Bis-[1-(4-substituted phenyl)-ethyl]-piperazine-2,3-dione derivatives (2a-i). The structures of the target compounds were elucidated depending upon the data of the different spectral as well as the elemental methods of analyses. In addition, a mass spectrum, for a representative example, was carried out where the expected fragmentation pattern is in accordance with the structure of the considered compound. The lipophilicity of the target compounds as expressed from the ClogP and the measured $R_{f}$ remarkably supercede that of piperazine. The preliminary anthelmintic activity of the newly synthesized derivatives (2a-i) was investigated in vitro against Enterobiuos vermicularis and Fasciola hepatica. The tested compounds exhibited, in all cases, considerable inhibitory effects on the growth of the tested parasites in comparison with piperazine hydrate as a reference drug.

\section{INTRODUCTION}

The prevalence of human helimenthic infestations is a widespread throughout the globe and represents a major world health problem, particularly in the third world countries. ${ }^{1}$ Several classes of chemical are used as anthelmintics and include phenols and derivatives, piperazine and related compounds, antimalarial compounds and natural products. ${ }^{2}$ On the other hand, a diversity of biological effects is possessed by compounds comprising the piperazine nucleus such as antipsychotic, ${ }^{3}$ antimalarial, ${ }^{4}$ histamine H1-receptor

Received in 4/10/2004 \& Accepted in 27/11/2004 
antagonist, ${ }^{5} \sigma$ site selective ligands, ${ }^{6,7}$ 5HT3 and 5-HT4 receptor ligands ${ }^{8}$ and $\delta$ opioid receptor agonist. ${ }^{9}$ In view of the wide spectrum of useful biological activities of piperazine compounds further exploratory synthesis of compounds built up on piperazine skeleton was done. On the other hand, it is reported that, the anthelminitic activity of piperazine and related compounds had been suggested to be, based on blockage of the response of the worm muscle to acetylcholine, causing a flaccid paralysis in the worm, which is dislodged from the intestinal wall and expelled in the feces. ${ }^{2}$

The present study is devoted to the synthesis of some new compounds comprising the piperazine-2,3-dione nucleus, and modulation of the lipophilic properties of the target compounds depending upon the use of different substituents and the degree of branching, structure I. Moreover, the biological activity of the target compounds was tested, if any.

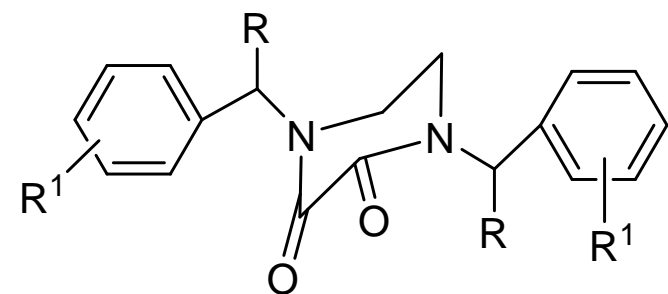

I

\section{EXPERIMENTAL}

Melting points were determined on an electrothermal melting point apparatus [Sturat Scientific, UK], and were uncorrected. Precoated silica gel plates (kiesel gel $0.25 \mathrm{~mm}$, 60G F254, Merk) were used for thin layer chromatography. Developing solvent system of chloroform/methanol (5:3) or Hexane/ethyl acetate (3:1) were used and the spots were visualized by ultraviolet light and/or iodine.

The IR spectra ( $\mathrm{KBr}$ disc or neat) were recorded on IR-470 Shimadzu spectrometer, Japan. The ${ }^{1}$ H-NMR Spectra were scanned on a Varian EM-360 L NMR spectrometer (60 MHZ) USA. Chemical shifts are expressed in $\delta$-values (ppm) relative to TMS as an internal standard, using $\mathrm{CDCl}_{3}$ as a solvent. The mass spectra were made on JEOL JMS600 mass spectrometer Japan at Assiut University Central Laboratory, Assiut, Egypt. Elemental analyses were performed at the Department of Chemistry, Faculty of Science, Assiut University, Assiut, Egypt. The log P values were computed with a routine method called calculated $\log \mathrm{P}(\mathrm{C} \log \mathrm{P})$ contained in a PCsoftware package (McLogP 2.0, BioByte Corp., CA, USA). The anthelmintic activity was performed at the Department of Parasitology, Faculty of Medicine, Assiut University, Assiut, Egypt.

\section{Chemistry}

Synthesis of $N, N$-Bis-(4-substituted benzyl)and $N, N$-Bis-[1-(4-substituted phenyl)ethyl]-ethane-1,2-diamine derivatives $(1 \mathrm{a}-\mathrm{i})^{10}$

To a solution of ethylenediamine $(30.0$ mmole) and the appropriate carbonyl compound $(60.0 \mathrm{mmole})$ in methanol $(50 \mathrm{~mL})$ was added sodium cyanoborohydride (48.0 mmole) portionwise at $0^{\circ}$. After stirring for 3 $\mathrm{hr}$ at ambient temperature, an additional amount of sodium cyanoborohydride (8.1 mmole) was added and stirring was continued for further $\mathbf{2 h}$. The reaction mixture was quenched with water, concentrated and extracted with chloroform. The combined organic extract was washed with brine and dried $\left(\mathrm{Na}_{2} \mathrm{SO}_{4}\right)$. Concentration and column chromatography $\left(\mathrm{CHCl}_{3} / \mathrm{MeOH}\right)$ afforded compounds (1a-i) as pale yellow oils. Yields and ${ }^{1}$ HNMR data are given in Table 1.

Synthesis of 1,4-Bis-(4-substituted benzyl)and 1,4-Bis-[1-(4-substituted phenyl)-ethyl]piperazine-2,3-dione (2a-i)

A mixture of $N, N^{\prime}$-Bis-(4-substituted benzyl)- or $N, N$-Bis-[1-(4-substituted phenyl)ethyl]-ethane-1,2-diamine derivatives, compounds 1a-h (7.5 mmole) and freshly distilled diethyl oxalate $(7.5$ mmole $)$ in dry ether $(10 \mathrm{~mL})$ was stirred at ambient temperature for $1 \mathrm{hr}$. The reaction mixture was left overnight and the separated solid product was obtained by filtration and dried. The crude products were crystallized from a mixture of ethanol and ether affording the target compounds 2a-h. The physicochemical constants and the spectral data are given in Tables 2 and 3 . 
Table 1: The yields and the ${ }^{1}$ HNMR data of compounds (1a-i)*.

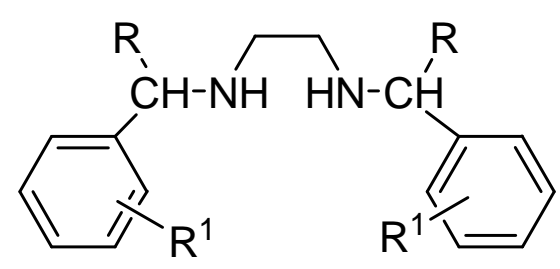

\begin{tabular}{|c|c|c|c|c|}
\hline $\begin{array}{l}\text { Compd. } \\
\text { No. }\end{array}$ & $\mathrm{R}$ & $\mathrm{R}^{1}$ & $\begin{array}{c}\text { Yield } \\
\%\end{array}$ & ${ }^{1} \mathrm{HNMR}$ data \\
\hline $1 a^{* *}$ & $\mathrm{H}$ & $\mathrm{H}$ & 64 & $\begin{array}{l}1.75(\mathrm{brs}, 2 \mathrm{H}, 2 \mathrm{NH}), 2.80\left(\mathrm{~s}, 4 \mathrm{H}, \mathrm{CH}_{2} \mathrm{CH}_{2}\right), 3.90 \\
\left.\text { (brs, } 4 \mathrm{H}, 2 \mathrm{CH}_{2}\right) \text {, and } 7.20(\mathrm{~s}, 10 \mathrm{H}, 2 \mathrm{Ar}-\mathrm{H}) .\end{array}$ \\
\hline $1 b$ & $\mathrm{H}$ & $p$-Br & 76 & $\begin{array}{l}1.80(\mathrm{brs}, 2 \mathrm{H}, 2 \mathrm{NH}), 2.67\left(\mathrm{~s}, 4 \mathrm{H}, \mathrm{CH}_{2} \mathrm{CH}_{2}\right), 3.64 \\
\left(\mathrm{brs}, 4 \mathrm{H}, 2 \mathrm{CH}_{2}\right) \text {, and } 7.34(8 \mathrm{H}, \mathrm{dd}, 2 \mathrm{Ar}-\mathrm{H}) .\end{array}$ \\
\hline 1c & $\mathrm{H}$ & $p-\mathrm{Cl}$ & 75 & $\begin{array}{l}1.74(\mathrm{brs}, 2 \mathrm{H}, 2 \mathrm{NH}), 2.80\left(\mathrm{~s}, 4 \mathrm{H}, \mathrm{CH}_{2} \mathrm{CH}_{2}\right), 3.84 \\
\left(\mathrm{~s}, 4 \mathrm{H}, 2 \mathrm{CH}_{2}\right) \text {, and } 7.40(\mathrm{~s}, 8 \mathrm{H}, 2 \mathrm{Ar}-\mathrm{H}) .\end{array}$ \\
\hline 1d & $\mathrm{H}$ & $o-\mathrm{OH}$ & 68 & $\begin{array}{l}1.85(\mathrm{brs}, 2 \mathrm{H}, 2 \mathrm{NH}), 2.67\left(\mathrm{~s}, 4 \mathrm{H}, \mathrm{CH}_{2} \mathrm{CH}_{2}\right), 3.90 \\
(\mathrm{~s}, 2 \mathrm{H}, 2 \mathrm{OH}), 4.67\left(\mathrm{~s}, 4 \mathrm{H}, 2 \mathrm{CH}_{2}\right) \text { and } 7.40(\mathrm{~s}, \\
8 \mathrm{H}, 2 \mathrm{Ar}-\mathrm{H}) .\end{array}$ \\
\hline $1 e$ & $\mathrm{CH}_{3}$ & $\mathrm{H}$ & 70 & $\begin{array}{l}1.34\left(\mathrm{~d}, 6 \mathrm{H}, 2 \mathrm{CH}_{3}\right), 1.64(\mathrm{brs}, 2 \mathrm{H}, 2 \mathrm{NH}), 2.57(\mathrm{~s}, \\
\left.4 \mathrm{H}, \mathrm{CH}_{2} \mathrm{CH}_{2}\right), 3.44-4.00(\mathrm{~m}, 2 \mathrm{H}, 2 \mathrm{CH}) \text {, and } 7.24 \\
(\mathrm{~s}, 10 \mathrm{H}, 2 \mathrm{Ar}-\mathrm{H}) \text {. }\end{array}$ \\
\hline 1f & $\mathrm{CH}_{3}$ & $p-\mathrm{Br}$ & 80 & $\begin{array}{l}1.30\left(\mathrm{~d}, 6 \mathrm{H}, 2 \mathrm{CH}_{3}\right), 1.90(\mathrm{brs}, 2 \mathrm{H}, 2 \mathrm{NH}), 2.54(\mathrm{~s}, \\
\left.4 \mathrm{H}, \mathrm{CH}_{2} \mathrm{CH}_{2}\right), 3.47-4.00(\mathrm{~m}, 2 \mathrm{H}, 2 \mathrm{CH}) \text {, and } 7.40 \\
(\mathrm{dd}, 8 \mathrm{H}, 2 \mathrm{Ar}-\mathrm{H}) .\end{array}$ \\
\hline $1 g$ & $\mathrm{CH}_{3}$ & $p$-Cl & 80 & $\begin{array}{l}1.27\left(\mathrm{~d}, 6 \mathrm{H}, 2 \mathrm{CH}_{3}\right), 1.67(\mathrm{brs}, 2 \mathrm{H}, 2 \mathrm{NH}), 2.47(\mathrm{~s}, \\
\left.4 \mathrm{H}, \mathrm{CH}_{2} \mathrm{CH}_{2}\right), 3.40-3.87(\mathrm{~m}, 2 \mathrm{H}, 2 \mathrm{CH}) \text {, and } 7.24 \\
(\mathrm{~s}, 8 \mathrm{H}, 2 \mathrm{Ar}-\mathrm{H}) .\end{array}$ \\
\hline 1h & $\mathrm{CH}_{3}$ & $p-\mathrm{CH}_{3}$ & 75 & $\begin{array}{l}1.34\left(\mathrm{~d}, 6 \mathrm{H}, 2 \mathrm{CH}_{3}\right), 1.70(\mathrm{brs}, 2 \mathrm{H}, 2 \mathrm{NH}), 2.34(\mathrm{~s}, \\
\left.6 \mathrm{H}, 2 \mathrm{CH}_{3} \mathrm{Ph}\right), 2.60\left(\mathrm{~s}, 4 \mathrm{H}, 2 \mathrm{CH}_{2}\right), 3.44-4.00(\mathrm{~m}, \\
2 \mathrm{H}, 2 \mathrm{CH}) \text {, and } 7.30(\mathrm{~s}, 8 \mathrm{H}, 2 \mathrm{Ar}-\mathrm{H}) .\end{array}$ \\
\hline $1 \mathbf{i}$ & $\mathrm{CH}_{3}$ & $p-\mathrm{OCH}_{3}$ & 78 & $\begin{array}{l}1.34\left(\mathrm{~d}, 6 \mathrm{H}, 2 \mathrm{CH}_{3}\right), 2.10(\mathrm{brs}, 2 \mathrm{H}, 2 \mathrm{NH}), 2.60(\mathrm{~s}, \\
\left.4 \mathrm{H}, 2 \mathrm{CH}_{2}\right), 3.87\left(\mathrm{~s}, 6 \mathrm{H}, 2 \mathrm{OCH}_{3}\right) \text {, and } 7.20(\mathrm{dd}, \\
8 \mathrm{H}, 2 \mathrm{Ar}-\mathrm{H}) .\end{array}$ \\
\hline
\end{tabular}

*All the compounds are viscous in nature. ** Compounds 1a, 1c, and 1d, are reported ${ }^{10}$. 
Table 2: 1,4-Disubstituted-piperazine-2,3-dione derivatives (2a-i).

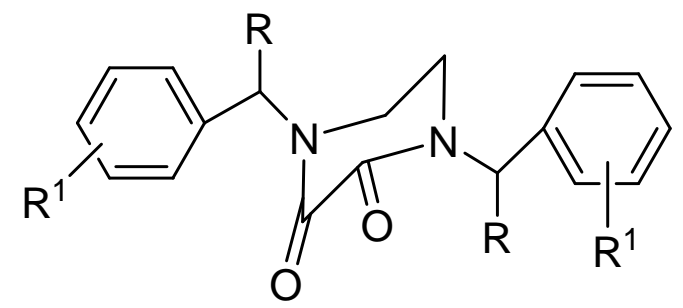

\begin{tabular}{|c|c|c|c|c|c|c|c|c|c|c|}
\hline \multirow[b]{2}{*}{$\begin{array}{c}\text { Compd. } \\
\text { No. }\end{array}$} & \multirow[b]{2}{*}{$\mathrm{R}$} & \multirow[b]{2}{*}{$\mathrm{R}^{1}$} & \multirow[b]{2}{*}{ Mol. Formula } & \multirow[b]{2}{*}{$\begin{array}{c}\text { Yield } \\
\% \\
\end{array}$} & \multirow[b]{2}{*}{$\mathrm{MP},{ }^{\circ}$} & \multirow[b]{2}{*}{$\mathrm{R}_{\mathrm{f}}$} & \multicolumn{3}{|c|}{ Microanalysis } & \multirow[b]{2}{*}{$\begin{array}{c}\text { Clog } \\
\text { p }^{*}\end{array}$} \\
\hline & & & & & & & & $\begin{array}{c}\text { Calcd. } \\
\%\end{array}$ & $\begin{array}{c}\text { Found } \\
\%\end{array}$ & \\
\hline $2 \mathbf{a}$ & $\mathrm{H}$ & $\mathrm{H}$ & $\begin{array}{c}\mathrm{C}_{18} \mathrm{H}_{18} \mathrm{~N}_{2} \mathrm{O}_{2} \\
(294.14)\end{array}$ & 55 & $220-2$ & 0.50 & $\begin{array}{l}\mathrm{C} \\
\mathrm{H} \\
\mathrm{N}\end{array}$ & $\begin{array}{c}73.45 \\
6.16 \\
9.52\end{array}$ & $\begin{array}{c}73.53 \\
5.95 \\
9.65\end{array}$ & 2.34 \\
\hline $2 b$ & $\mathrm{H}$ & $p-\mathrm{Br}$ & $\begin{array}{c}\mathrm{C}_{18} \mathrm{H}_{16} \mathrm{Br}_{2} \mathrm{~N}_{2} \mathrm{O}_{2} \\
(451.96)\end{array}$ & 78 & $215-7$ & 0.56 & $\begin{array}{l}\mathrm{C} \\
\mathrm{H} \\
\mathrm{N} \\
\end{array}$ & $\begin{array}{c}47.82 \\
3.57 \\
6.20 \\
\end{array}$ & $\begin{array}{c}47.51 \\
3.28 \\
6.41 \\
\end{array}$ & 3.99 \\
\hline $2 c$ & $\mathrm{H}$ & $p-\mathrm{Cl}$ & $\begin{array}{c}\mathrm{C}_{18} \mathrm{H}_{16} \mathrm{Cl}_{2} \mathrm{~N}_{2} \mathrm{O}_{2} \\
(363.24)\end{array}$ & 86 & $207-8$ & 0.51 & $\begin{array}{l}\mathrm{C} \\
\mathrm{H} \\
\mathrm{N} \\
\end{array}$ & $\begin{array}{c}59.52 \\
4.44 \\
7.71 \\
\end{array}$ & $\begin{array}{c}59.98 \\
5.09 \\
8.12 \\
\end{array}$ & 3.82 \\
\hline $2 d$ & $\mathrm{H}$ & $o-\mathrm{OH}$ & $\begin{array}{c}\mathrm{C}_{18} \mathrm{H}_{18} \mathrm{~N}_{2} \mathrm{O}_{4} \\
(326.13)\end{array}$ & 63 & $230-1$ & 0.28 & $\begin{array}{l}\mathrm{C} \\
\mathrm{H} \\
\mathrm{N}\end{array}$ & $\begin{array}{c}66.25 \\
5.56 \\
8.58\end{array}$ & $\begin{array}{c}65.63 \\
5.41 \\
8.49\end{array}$ & 1.56 \\
\hline $2 e$ & $\mathrm{CH}_{3}$ & $\mathrm{H}$ & $\begin{array}{c}\mathrm{C}_{20} \mathrm{H}_{22} \mathrm{~N}_{2} \mathrm{O}_{2} \\
(322.17)\end{array}$ & 60 & $190-1$ & 0.52 & $\begin{array}{l}\mathrm{C} \\
\mathrm{H} \\
\mathrm{N} \\
\end{array}$ & $\begin{array}{c}74.51 \\
6.88 \\
8.69 \\
\end{array}$ & $\begin{array}{c}74.55 \\
7.24 \\
7.99 \\
\end{array}$ & 2.97 \\
\hline $2 f$ & $\mathrm{CH}_{3}$ & $p$-Br & $\begin{array}{c}\mathrm{C}_{20} \mathrm{H}_{20} \mathrm{Br}_{2} \mathrm{~N}_{2} \mathrm{O}_{2} \\
(479.99)\end{array}$ & 85 & $165-7$ & 0.63 & $\begin{array}{l}\mathrm{C} \\
\mathrm{H} \\
\mathrm{N} \\
\end{array}$ & $\begin{array}{c}50.02 \\
4.20 \\
5.83 \\
\end{array}$ & $\begin{array}{c}50.33 \\
3.99 \\
6.10 \\
\end{array}$ & 4.63 \\
\hline $2 g$ & $\mathrm{CH}_{3}$ & $p-\mathrm{Cl}$ & $\begin{array}{c}\mathrm{C}_{20} \mathrm{H}_{20} \mathrm{Cl}_{2} \mathrm{~N}_{2} \mathrm{O}_{2} \\
(390.09)\end{array}$ & 75 & $135-6$ & 0.52 & $\begin{array}{l}\mathrm{C} \\
\mathrm{H} \\
\mathrm{N}\end{array}$ & $\begin{array}{c}61.39 \\
5.15 \\
7.16\end{array}$ & $\begin{array}{c}61.45 \\
5.34 \\
7.23\end{array}$ & 4.09 \\
\hline $2 \mathrm{~h}$ & $\mathrm{CH}_{3}$ & $p-\mathrm{CH}_{3}$ & $\begin{array}{c}\mathrm{C}_{22} \mathrm{H}_{26} \mathrm{~N}_{2} \mathrm{O}_{2} \\
(350.20)\end{array}$ & 70 & $205-7$ & 0.60 & $\begin{array}{l}\mathrm{C} \\
\mathrm{H} \\
\mathrm{N} \\
\end{array}$ & $\begin{array}{c}75.40 \\
7.48 \\
7.99 \\
\end{array}$ & $\begin{array}{c}75.43 \\
7.55 \\
8.10 \\
\end{array}$ & 3.95 \\
\hline $2 \mathbf{i}$ & $\mathrm{CH}_{3}$ & $p-\mathrm{OCH}_{3}$ & $\begin{array}{c}\mathrm{C}_{22} \mathrm{H}_{26} \mathrm{~N}_{2} \mathrm{O}_{4} \\
(382.19)\end{array}$ & 69 & $191-2$ & 0.49 & $\begin{array}{l}\mathrm{C} \\
\mathrm{H} \\
\mathrm{N}\end{array}$ & $\begin{array}{c}69.09 \\
6.85 \\
7.32\end{array}$ & $\begin{array}{c}70.10 \\
6.75 \\
7.42\end{array}$ & 2.72 \\
\hline
\end{tabular}

* The Clog $\mathrm{P}$ for piperazine is -1.13 . 
Table 3: ${ }^{1}$ HNMR chemical shifts of compounds (2a-i).

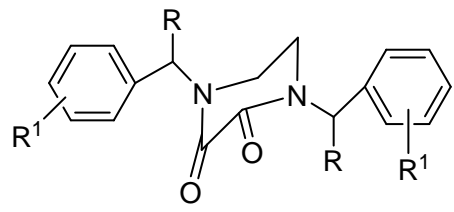

\begin{tabular}{|c|c|c|c|}
\hline $\begin{array}{l}\text { Compd. } \\
\text { No. }\end{array}$ & $\mathrm{R}$ & $\mathrm{R}^{1}$ & ${ }^{1} \mathrm{HNMR}$ data \\
\hline $2 \mathbf{a}$ & $\mathrm{H}$ & $\mathrm{H}$ & $\begin{array}{l}3.50\left(\mathrm{~s}, 4 \mathrm{H}, \mathrm{CH}_{2} \mathrm{CH}_{2}\right), 4.70,\left(\mathrm{~s}, 4 \mathrm{H}, 2 \mathrm{CH}_{2} \mathrm{Ph}\right) \text {, and } 7.20- \\
7.90(\mathrm{~m}, 10 \mathrm{H}, 2 \mathrm{Ar}-\mathrm{H}) .\end{array}$ \\
\hline $2 \mathrm{~b}$ & $\mathrm{H}$ & $p-\mathrm{Br}$ & $\begin{array}{l}3.47\left(\mathrm{~s}, 4 \mathrm{H}, \mathrm{CH}_{2} \mathrm{CH}_{2}\right), 4.70\left(\mathrm{~s}, 4 \mathrm{H}, 2 \mathrm{CH}_{2} \mathrm{Ph}\right) \text {, and } 7.14- \\
7.87(\mathrm{~m}, 8 \mathrm{H}, 2 \mathrm{Ar}-\mathrm{H}) \text {. }\end{array}$ \\
\hline $2 c$ & $\overline{\mathrm{H}}$ & $p-\mathrm{Cl}$ & $\begin{array}{l}3.40\left(\mathrm{~s}, 4 \mathrm{H}, \mathrm{CH}_{2} \mathrm{CH}_{2}\right), 4.67\left(\mathrm{~s}, 4 \mathrm{H}, 2 \mathrm{CH}_{2} \mathrm{Ph}\right) \text {, and } 7.37(\mathrm{~s}, \\
8 \mathrm{H}, 2 \mathrm{Ar}-\mathrm{H}) .\end{array}$ \\
\hline $2 d$ & $\mathrm{H}$ & $o-\mathrm{OH}$ & $\begin{array}{l}3.57\left(\mathrm{~s}, 4 \mathrm{H}, 2 \mathrm{CH}_{2}\right), 4.67\left(\mathrm{~s}, 4 \mathrm{H}, 2 \mathrm{CH}_{2} \mathrm{Ph}\right), 6.67-7.70(\mathrm{~m}, \\
8 \mathrm{H}, 2 \mathrm{Ar}-\mathrm{H}) \text {, and } 9.77(\mathrm{brs}, 1 \mathrm{H}, \mathrm{OH} \text {, exchangeable with } \\
\left.\mathrm{D}_{2} \mathrm{O}\right) \text {. }\end{array}$ \\
\hline $2 \mathrm{e}$ & $\mathrm{CH}_{3}$ & $\mathrm{H}$ & $\begin{array}{l}1.57\left(\mathrm{~d}, 6 \mathrm{H}, 2 \mathrm{CH}_{3}\right), 2.70-3.30\left(\mathrm{~m}, 4 \mathrm{H}, 2 \mathrm{CH}_{2}\right), 6.00(\mathrm{q}, \\
2 \mathrm{H}, 2 \mathrm{CH}) \text {, and } 7.34(\mathrm{~m}, 10 \mathrm{H}, 2 \mathrm{Ar}-\mathrm{H}) .\end{array}$ \\
\hline $2 f$ & $\mathrm{CH}_{3}$ & $p$-Br & $\begin{array}{l}1.54\left(\mathrm{~d}, 6 \mathrm{H}, 2 \mathrm{CH}_{3}\right), 2.64-3.70\left(\mathrm{~s}, 4 \mathrm{H}, 2 \mathrm{CH}_{2}\right), 6.00(\mathrm{q}, \\
2 \mathrm{H}, 2 \mathrm{CH}) \text {, and } 7.44(\mathrm{dd}, 8 \mathrm{H}, 2 \mathrm{Ar}-\mathrm{H}) .\end{array}$ \\
\hline $2 g$ & $\mathrm{CH}_{3}$ & $p-\mathrm{Cl}$ & $\begin{array}{l}1.50\left(\mathrm{~d}, 6 \mathrm{H}, 2 \mathrm{CH}_{3}\right), 2.84\left(\mathrm{~m}, 4 \mathrm{H}, 2 \mathrm{CH}_{2}\right), 5.70(\mathrm{q}, 2 \mathrm{H}, \\
2 \mathrm{CH}) \text {, and } 7.44(\mathrm{~s}, 8 \mathrm{H}, 2 \mathrm{Ar}-\mathrm{H}) .\end{array}$ \\
\hline $2 \mathrm{~h}$ & $\mathrm{CH}_{3}$ & $p-\mathrm{CH}_{3}$ & $\begin{array}{l}1.40 \text { and } 1.57\left(\mathrm{~d}, \text { each } 3 \mathrm{H}, 2 \mathrm{CH}_{3}\right), 2.40\left(\mathrm{~s}, 6 \mathrm{H}, 2 \mathrm{CH}_{3} \mathrm{Ph}\right) \text {, } \\
2.77-3.44\left(\mathrm{~m}, 4 \mathrm{H}, 2 \mathrm{CH}_{2}\right), 6.14(\mathrm{q}, 2 \mathrm{H}, 2 \mathrm{CH}) \text {, and } 7.37(\mathrm{~s}, \\
8 \mathrm{H}, 2 \mathrm{Ar}-\mathrm{H}) \text {. }\end{array}$ \\
\hline $2 \mathbf{i}$ & $\mathrm{CH}_{3}$ & $p-\mathrm{OCH}_{3}$ & $\begin{array}{l}1.40 \text { and } 1.57\left(\mathrm{~d} \text {, each } 3 \mathrm{H}, 2 \mathrm{CH}_{3}\right), 2.64-3.67(\mathrm{~m}, 4 \mathrm{H}, \\
\left.2 \mathrm{CH}_{2}\right), 3.70\left(\mathrm{~s}, 6 \mathrm{H}, 2 \mathrm{OCH}_{3}\right), 6.10(\mathrm{q}, 2 \mathrm{H}, 2 \mathrm{CH}) \text {, and } \\
7.20(\mathrm{dd}, 8 \mathrm{H}, 2 \mathrm{Ar}-\mathrm{H}) .\end{array}$ \\
\hline
\end{tabular}

\section{Calculation of the $\log P$ values}

The $\log \mathrm{P}$ values of the target compounds (2a-i) as well as piperazine hydrate, were computed with a routine method called calculated $\log \mathrm{P}(\mathrm{C} \log \mathrm{P})$ contained in a PCsoftware package (McLogP 2.0, BioByte Corp., CA, USA). A representation of the molecular structure where hydrogens are omitted or 'suppressed' (SMILES notation) is entered into the program, which computes the log $\mathrm{P}$ based on the fragment method developed by A.J. Leo, ${ }^{11}$ the results are given in Table 2 .

\section{Anthelmintic Activity}

The synthesized compounds (2a-i) were evaluated in vitro for their anthelmintic activities according to a standard protocol mentioned below. ${ }^{12,13}$

\section{Parasites, culture conditions, and anthelmintic activity}

Entrobius vermicularis ${ }^{12}$ was collected from patients in private lab and transferred in saline immediately to the lab of study. Fasciola hepatica $^{13}$ was collected from slaughterhouse and transferred in saline immediately to the lab of study. The parasites were washed several times by saline and put in Petri dishes as living in saline and incubated at $37^{\circ}$ for $6 \mathrm{hrs}$. The solutions of the tested compounds $(100 \mu$ mole $)$ in dimethyl sulphoxide $(5 \mathrm{~mL})$ were added and the numbers of the dead worms are recorded in each solution as well as for the reference drug and a control experiment. 


\section{RESULTS AND DISCUSSION}

\section{Chemistry}

The synthesis of $N, N^{\prime}$-disubstitutedpiperazine-2,3-dione derivatives has been carried out according to steps in scheme 1 .
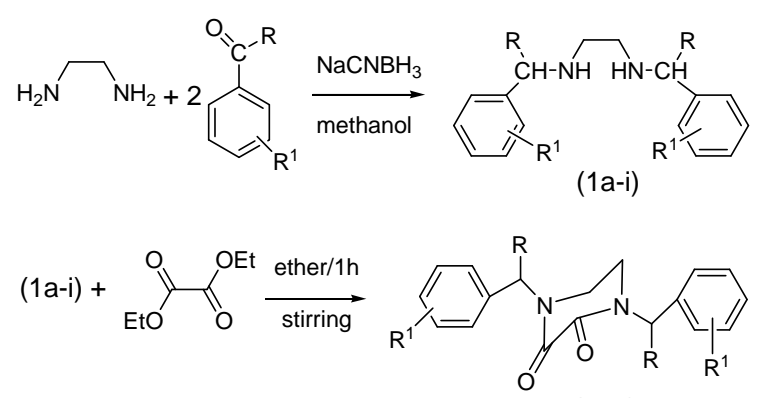

$(2 \mathrm{a}-\mathrm{i})$

\begin{tabular}{||c|c|c|}
\hline $\mathbf{1}$ and 2 & $\mathbf{R}$ & $\mathbf{R}^{\mathbf{1}}$ \\
\hline $\mathrm{a}$ & $\mathrm{H}$ & $\mathrm{H}$ \\
$\mathrm{b}$ & $\mathrm{H}$ & $p-\mathrm{Br}$ \\
$\mathrm{c}$ & $\mathrm{H}$ & $p-\mathrm{Cl}$ \\
$\mathrm{d}$ & $\mathrm{H}$ & $o-\mathrm{OH}$ \\
$\mathrm{e}$ & $\mathrm{CH}_{3}$ & $\mathrm{H}$ \\
$\mathrm{f}$ & $\mathrm{CH}_{3}$ & $p-\mathrm{Br}$ \\
$\mathrm{g}$ & $\mathrm{CH}_{3}$ & $p-\mathrm{Cl}$ \\
$\mathrm{h}$ & $\mathrm{CH}_{3}$ & $p-\mathrm{CH}_{3}$ \\
$\mathrm{i}$ & $\mathrm{CH}_{3}$ & $p-\mathrm{OCH}_{3}$ \\
\hline
\end{tabular}

Scheme 1

In the first step, the appropriate carbonyl compounds were reacted with ethylenediamine in the presence of sodium cyanoborohydride to afford $N, N^{\top}$-Bis-(4-substituted benzyl)-ethane1,2-diamine and $N, N^{\top}$-Bis-[1-(4-substituted phenyl)-ethyl]-ethane-1,2-diamine derivatives (1a-i) through reductive alkylation reaction that are viscous in nature. Compounds (1a-i), were subjected to cyclization process through the reaction with diethyl oxalate affording the target compounds, (2a-i), with yields varying from $55-86 \%$, Scheme 1 . The physicochemical constants of compounds (2a-i) are reported in Table 2.

The structures of the synthesized compounds were verified on the bases of spectral as well as elemental methods of analyses. The structures of the intermediate compounds (1a-i) are clarified depending upon the IR and the ${ }^{1} \mathrm{HNMR}$ spectral data and in part with the reported data. ${ }^{11}$ The IR spectra of the intermediate compounds (1a-i) showed strong broadband at about 3350-3400 (2NH stretching). On the other hand, in the ${ }^{1} \mathrm{HNMR}$ a common singlet signal for the two methylene groups was observed beside another singlet signal equivalent to four protons of the introduced carbonyl compound in the case of $N, N$-Bis-(4-substituted benzyl)-ethane-1,2diamine or a doublet signal equivalent to six protons of two methyl groups and a quartet signal equivalent to two protons of the 2 methine protons in the case of $N, N^{-}$-Bis-[1-(4substituted phenyl)-ethyl]-ethane-1,2-diamine derivatives. Moreover, the presence of a broad signal equivalent to two protons (exchangeable by treatment with $\mathrm{D}_{2} \mathrm{O}$ ) of the two $\mathrm{NH}$ groups and the aromatic protons are other evidences of the structure of such derivatives.

All the spectral data of the target compounds are in accordance with the proposed structures. The IR spectra of compounds 2a-i show prominent very strong absorption bands around 1653-1671 (2 C=O stretch). In the ${ }^{1} \mathrm{HNMR}$ spectra, Table 3 , a common signal for the two methylene groups of the piperzine-2,3-dione nucleus was observed. The differences in sets and patterns were only attributed to the 1,4-disubstituents, where they give patterns in accordance with the expected structures of the target compounds, Table 3.

Moreover, the structures of the target compounds were additionally clarified on the basis of the fragmentation pattern of a representative example, compounds $2 \mathrm{~h}$. The mass spectrum of compound $2 \mathrm{~h}$ shows a molecular ion peak at $\mathrm{m} / \mathrm{z} \quad 350 \quad(32 \%)$ corresponding to the moleculer weight of the compound and characterized by two prominent peaks at $\mathrm{m} / z 230(53 \%)$, and $119(100 \%)$ due to fragmentation of the N1 or N4 substituents. In addition the data reveal the presence of the very charactersitic tropylium cation at $\mathrm{m} / \mathrm{z} 91$ $(15 \%)$.

\section{Lipophilicity}

The lipophilicity of the target compounds (2a-i) as well as piperazine hydrate, is expressed on the term of Clog $\mathrm{P}$ values. The values were computed with a routine method called calculated $\log \mathrm{P}(\mathrm{C} \log \mathrm{P})$ contained in a $\mathrm{PC}$-software package as will be mentioned in 
the experimental section. A program, which computes the $\log \mathrm{P}$ based on the fragment method developed by A.J. Leo, ${ }^{11}$ the results are given in Table 2.

As given in Table 2, there is a considerable improvement in the lipophilicity of the target compounds (2a-i) in comparison with the reference drug piperazine. Moreover, there is a relationship between the values of the Clog $\mathrm{P}$ and those of the $\mathrm{R}_{\mathrm{f}}$ measured for these compounds. Thus these new compounds may possess the ability for penetration of various biomembranes that enhances their bioavailability to the site of action. ${ }^{14}$

\section{Anthelmintic activities}

The anthelmintic activities of the target compounds were tested against Enterobious vermicularis and Fasciola hepatica according to a reported protocol described in the experimental part. ${ }^{12,13}$ Doses of the tested compounds for anthelmintic activities are given in Table 4, in comparison with the reference drugs.

Table 4: Doses of compounds (2a-i) and piperazine hydrate for anthelmintic activity.

\begin{tabular}{|c|c|c|c|}
\hline $\begin{array}{c}\text { Compd. } \\
\text { No. }\end{array}$ & $\mathrm{R}$ & $\mathrm{R}^{1}$ & $\mathrm{mg} / 5 \mathrm{ml}$ \\
\hline $2 \mathrm{a}$ & $\mathrm{H}$ & $\mathrm{H}$ & 29.4 \\
\hline $2 b$ & $\mathrm{H}$ & $p$-Br & 45.1 \\
\hline $2 c$ & $\mathrm{H}$ & $p-\mathrm{Cl}$ & 36.3 \\
\hline $2 \mathrm{~d}$ & $\mathrm{H}$ & $o-\mathrm{OH}$ & 32.6 \\
\hline $2 \mathrm{e}$ & $\mathrm{CH}_{3}$ & $\mathrm{H}$ & 32.2 \\
\hline $2 \mathrm{f}$ & $\mathrm{CH}_{3}$ & $p-\mathrm{Br}$ & 47.9 \\
\hline $2 \mathrm{~g}$ & $\mathrm{CH}_{3}$ & $p-\mathrm{Cl}$ & 39.0 \\
\hline $2 \mathrm{~h}$ & $\mathrm{CH}_{3}$ & $p-\mathrm{CH}_{3}$ & 35.0 \\
\hline $2 \mathrm{i}$ & $\mathrm{CH}_{3}$ & $p-\mathrm{OCH}_{3}$ & 38.2 \\
\hline \multicolumn{3}{|c|}{ Piperazine hydrate } & 19.4 \\
\hline
\end{tabular}

The results are observed as the percentage number of the dead worms in each case. All the tested compounds gave anthelmintic activity comparable to the reference drug used, piperazine hydrate, and the percentage number of the dead worms was $80-90 \%$ in each case over the period of observation (6 hrs). As a general pattern, the anthelmintic activities of the tested compounds under the used concentrations are almost independent on variation of the 1,4- side substituents. Accordingly, this series of compounds embedding the piperazine-2,3-dione moiety in its structure can be considered as promising candidates to be used as anthelmintic agents and consequently intensive in vitro and in vivo as well as the synthesis of new derivatives are in progress.

\section{Conclusion}

We can conclude that, a new series of new 1,4-disubstituted piperazine-2,3-dione derivatives were synthesized as the target compounds. The structures of the target compounds were elucidated depending upon the data of the different spectral as well as the elemental methods of analyses. In addition, a mass spectrum, for representative example, was carried out where the expected fragmentation mode is in accordance with the structures of the considered compounds. The anthelmintic activity of the newly synthesized compounds (2a-i) was investigated in vitro against Enterobiuos vermicularis and Fasciola hepatica. The tested compounds exhibited, in all cases, considerable inhibitory effects on the growth of the tested parasites in comparison with piperazine hydrate as a reference drug. Accordingly, this series of compounds embedding the piperazine-2,3-dione moiety in its structure can be considered as promising candidates to be used as anthelmintic agents and consequently intensive in vitro and in vivo as well as the synthesis of new derivatives are in progress.

\section{REFERENCES}

1- R. M. Amold, in "Wilson and Gisvold's Text Book of Organic Medicinal and Pharmaceutical Chemistry", $10^{\text {th }}$ Ed. Lippincott-Raven, New York, 1998, p 531.

2- Q. A. Feras, Xiao-Xi and L. M. Jerry, J. Nat. Prod., 62, 504, (1999).

3- Z. Xiaoyan, H. Kevin, R. Stanislaw, Z. He, W. F. W. Jan, C. Kimberly, B. Robbin, K. Andrzej, H. Diane, D. B. Maria, G. Brian, T. Jennifer and T. Andrew, J. Med. Chem., 43, 3923, (2000).

4- R. H. Thomas, M. P. Jeanne, V. S. Elvelen and O. G. Adolph, J. Med. Chem., 18, 12, 1216, (1975). 
5- B. Sandra, B. Enrico, S. Fedrico Da, D. Giulio, M. Concenttina La, M. M. Anna and P. Giampaolo, Eur. J. Med. Chem., 43, 93, (1999).

6- Y. Salome, L. Youssef, B. M. Genevie/ve, P. Marc, R. Marie-Claire, R. Pierre, P. Bruno and C. Daniel-Henri, Eur. J. Med. Chem., 35, 107, (2000).

7- M. Maria, S. Maria, G. Salvatore, R. Filippo, C. Alfredo, G. Mara and M. Tiziana, Eur. J. Med. Chem., 63, 287, (2001).

8- P. Niklas, D. Daniel, W. Zhong-Yong, Y. Hua, Z. Fei, S. Peter, G. Lars, G. Helene, P. Benjamin, S. Ralf, Y. Y. Shi, W. Christopher, B. William, Z. Edward, L. Maryse, P. Kemal, S. Stephene, K. Augustus, M. Pierre-Emmannuel, P. Denis, D. Julie and R. Edward, J. Med. Chem., 43, 3878, (2000).
9- Richard J. Martin, L. C. Cheryl, M. T. Sasa and P. R. Alan, Inter. J. for Parasitology; 34, 1083, (2004).

10- S. Vibha and M. S. Y. Khan, Eur. J. Med. Chem., 36, 651, (2001).

11- A. J. Leo, Chem. Rev., 93, 1281, (1993).

12- L. Bowman and S. Lynn, "Georgis' Pasasitology for Veterinarians", $7^{\text {th }}$ Ed., W. B. Sawders Company, 1999, p. 219.

13- P. S. Cecilia, G. M. Kelly, K. J. P. Liana, C. P. S. Glaucia, R. Fabio and K. Naftale, Men Inst Oswaldo Cruz Rio de Janeiro, 97, 3, 407, (2002).

14- J. M $\phi s s$ and H. Bundgaard, Int. J. Pharm., $66,39,(1990)$. 